\title{
Hybrid System Analysis using Solar and Wind Power
}

\author{
G.Esakkimuthu, Rajesh Krishnasamy, Ramkumar Aathi,
}

\begin{abstract}
Combination of Photo voltaic and wind power is the one of the best solution for providing cleaning and nonpolluting energy from two of the most abundant renewable energy sources. A few areas have a wealth of light energy while others have a plenitude of wind. Having a mix Hybrid system enables you to exploit the predominant climate conditions to amplify vitality generation. The electrical vitality (DC control) created utilizing Solar panel can be put away in batteries or can be utilized for providing $D C$ stacks or can be utilized for inverter to encourage AC loads. Solar Energy is accessible just amid the day time while wind vitality is accessible for the duration of the day relying on the climatic conditions. Wind and sun powered vitality are correlative to one another, which makes the framework to create power nearly consistentlys.
\end{abstract}

Keywords : Hybrid Energy system, AC,DC, Solar Energy, Wind Energy, Photo voltaic, Charge controller .

\section{INTRODUCTION}

$\mathrm{P}_{\text {resently multi day's electrical Energy is produced by the }}$ regular vitality assets like coal, diesel, and atomic and so forth. The rule drawback of these sources is that it produces waste like singing trash in coal power plant, atomic waste in atomic power plant and dealing with this wastage is all around expensive. Moreover, it in like manner harms the environment.

This type of waste is exceptionally hurtful to person. The regular vitality assets are draining step by step. A little while later it will do totally evaporates from the earth so we have to find another methodology to create power. The another source ought to be solid, contamination free and conservative.
The Hybrid solar wind Energy can be great elective source. Hybrid Energy systems are effectively accessible in all condition In a significant part of the United States, wind velocities are low in the late spring when the sun sparkles most splendid and longest. The breeze is solid in the winter when less daylight is accessible. Since the pinnacle working occasions for wind and heavenly bodies happen at various occasions of the day and year, mixture frameworks are bound to create control when you need it.

\section{A. Literature Survey}

\section{Poorani.S Professor-EEE-KAHE, Karpagam University,Coimbatore \\ Rajeswari Kalliappan -TNEB Executive}

In this paper was proposed idea is to come up with electrical control from windmill and electrical gadget and synchronizing with grid power offer. These days power demand is exaggerated extremely thus want the alternate power supply it's terribly helpful to come up with the electric control from regular resources so as to reimburse the electrical power demand. The mixture control age might be another creative origination that has planned during this venture. it's one among the non- traditional vitality; here creating the capacity offer from the natural resources and conjointly throughout global organization handiness of regular assets the EB power supply is employed for the load and too much generation of PV, wind factory offer is traded to the power matrix of the EB supply at any ideal voltage level. This task is planned with the accompanying parts are wind factory course of action, sun powered board, dynamo, rectifier, channel and battery and associated with the Electricity Board supply [12].

\section{HYBRID SYSTEM}

Most of the Hybrid systems are stand-alone systems, which work "off-grid" -- not associated with a power appropriation framework. For the occasions when not one or the other breeze nor the close planetary system are delivering, most half breed frameworks give control through batteries and additionally a motor generator controlled by ordinary powers, for example, diesel. In the event that the batteries run low, the motor generator can give control and energize the batteries. As indicated by numerous sustainable power source specialists, a little "cross breed" electric framework that consolidates wind and sun based vitality (photovoltaic or PV) innovations offers a few favorable circumstances over either single framework [1].

\section{A. Solar energy}

Sun based energy is that energy created or transmitted by the sun. Sun powered photovoltaic devices, or sun oriented cells, change

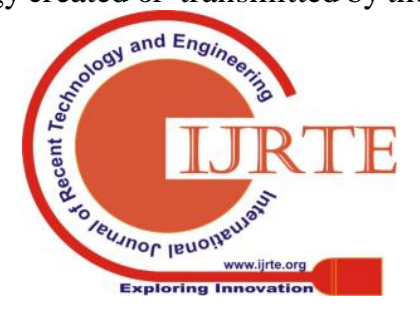


directly sun light energy into power. Little PV cells can control mini-computers, watches and other electrical devices. Arrangements of many solar cells in PV panels and arrangement of multiple PV panels in PV arrays can produce electricity. At the point when daylight hits the cells, it thumps electrons free from their iotas. As the electrons move through the cell, they create power.

\section{B. Wind Energy}

That turbine which is rotated by wind is connected to alternator, which is employed to get mechanical power into wattage. This is employed to come up with mechanical power into power [6]. Wind turbines convert the K.E. inside the breeze into mechanical power. This mechanical power is utilized for explicit undertakings like pounding grain or siphoning water. Cyberspace effects on the surroundings are way less problematic than those of fuel sources.

The critical weights of using self-sufficient supportable power source resources are that detachment of force until the end of time. For defeating this we use both irradiance based and wind vitality together. With the objective that any one wellspring of force comes up short other will manage the age. The proposed framework uses the two sources are combined this will prompts coherence of age. This will make framework solid. The major inconveniences of this framework are that it required high starting cost. Then again, actually it is solid, it has less discharge. Upkeep cost is less. Life expectancy of this framework is more. Productivity is more. There are various non-standard vitality assets are there like, tidal, wind, sun oriented and so forth the tidal vitality has some drawbacks like it can just actualized on ocean. While geothermal vitality needs very ale venture to extricate and heat from earth. solar based hybrid systems are effectively available in all condition. This paper manages the age of power by utilizing two sources consolidate which prompts create power with reasonable expense without harming the nature balance.

\section{DESIGN OF HYBRID ENERGY SYSTEMS}

Photo voltaic Module and wind makes the hybrid power system. In this experiment was conducted by using solar Photo voltaic module and small high speed permanent magnet DC generator for producing power. Generally, these Photo voltaic and wind half breed frameworks prepared to do little capacities. The normal power producing capacities of Photo voltaic and wind hybrid system are in the range of up to $10 \mathrm{kw}$. In this system both powers were stored in battery by using the charge controller. Both powers was controlled by inverter (DC/AC) and supply to the lighting system.

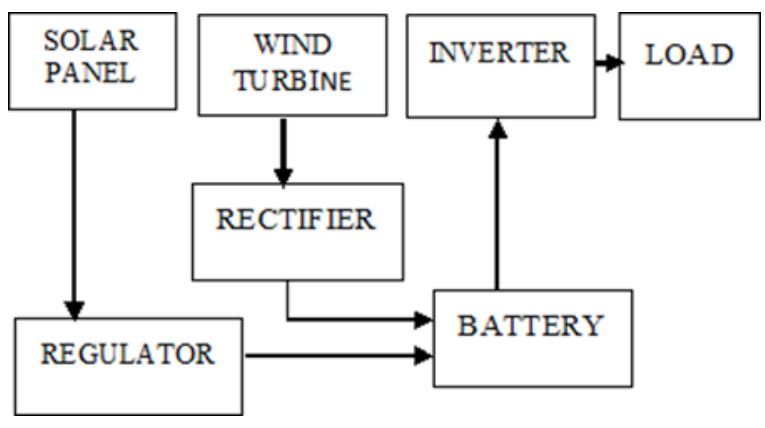

Fig. (i) Block diagram of Hybrid System

Above figure. (i) Shows the block diagram of the hybrid power generation system using wind and Photo voltaic system. This block diagram includes following blocks.

\section{A. Photo Voltaic Module}

The Photo voltaic module constructed by number of photo voltaic cells are associated in arrangement to acquire the required voltage [4]. Electrical vitality can be reaped from sun oriented PV framework by methods for either photo voltaic or concentrated sun based PV frameworks. Photo voltaic directly convert sun irradiance it means light energy into electricity. They work on the rule of the photovoltaic impact. At the point when certain materials are presented to light, they ingest photons and discharge free electrons. This wonder is called as the photoelectric effect. This impact is a technique for delivering direct flow power dependent on the rule of photoelectric impact. Be that as it may, single photovoltaic cell does not deliver enough measure of power; in this way the quantities of photovoltaic cells are mounted. It is intended to supply electric power at certain voltage level.

\begin{tabular}{|l|l|}
\hline Parameters & Unit \\
\hline Pmax & $10 \mathrm{~W}$ \\
\hline Tolerance of Production & $\pm 10.00 \%$ \\
\hline Voltage at Pmax & $17 \mathrm{~V}$ \\
\hline Current at Pmax & $0.55 \mathrm{~A}$ \\
\hline Current at short circuit & $0.60 \mathrm{~A}$ \\
\hline Cells thickness & $0.18 \mathrm{~mm} \pm 20 \mu \mathrm{m}$ \\
\hline size of panel (wide and high) & $340 * 280 * 22 \mathrm{~mm}$ \\
\hline
\end{tabular}

Table. 1 Photo Voltaic Module Parameter

\section{B. Wind Turbine}

Wind turbines transforms vitality in the breeze into power utilizing the streamlined power made by the rotor cutting edges, that work equally to Associate in Nursing airplanes wing or eggbeater surface. Once the wind stream over the cutting edge, the environmental weight on one aspect of the cutting edge diminishes. The qualification in climatic weight over the 2 sides of the edge makes each raise and drag [3]. The power of the raise is more grounded than the drag and this makes the rotor turn. The rotor is associated with the generator either legtimately through a shaft and a series of gears that speed up the rotation and permit for a physically smaller generator. This interpretation of streamlined power to revolution of a generator makes power. Wind turbine rating is $30 \mathrm{~W}$ and $12 \mathrm{~V}$.

\section{Rectifier}

In this experiment we tend to are victimization the bridge rectifier to convert $\mathrm{AC}$ to $\mathrm{DC}$. Whenever the instant price of the input AC voltage, a MOSFET is switched on to permit current to be due the input to the output. As we wish to own a full wave rectifier, we want four FETs rather than four diodes, even as in an exceedingly bridge rectifier. R1- R4 from a resistance for the corrected voltage and R5-R8 do constant for the AC input voltage. As presently because the corrected voltage, IC1d switches on MOSFET T3. This MOSFET diagonally opposite T3 should even be switched on at constant time. That's taken care of by IC1b.The polarity of

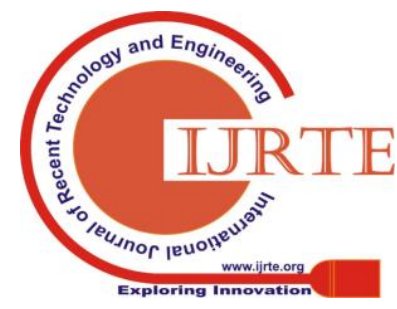


the AC voltages is reversed throughout subsequent halfwave, thus IC1c and IC1a put on T4 and T1, severally [6].

\section{Regulator}

This is an important part of the hybrid system or all power system that charge controller (or) regulator charges the batteries, Regardless of whether the power sources are solar panels, wind, hybrid, fuel, or the utility grid, its motivation is to keep your profound cycle batteries appropriately sustained and alright as long as possible. Regulator block reverse current and prevent battery overcharge, protect from electrical overload. This controller is a little box comprising of strong state hardware that is set between a sun solar panel and battery[13].

\section{E. Batteries}

In this project we are using $12 \mathrm{~V}, 7 \mathrm{AH}$ and SLA- 12V7-F1 Model and its charging and discharging time depends upon type of load used. This battery development is permit inconvenience free, safe activity in any position. There is no compelling reason to include electrolyte as gases produced during overcharge are recombined in a unique "OxygenCycle". The high-sway safe battery case is made of non-conductive plastic with better obstruction than stun vibration, synthetic substances and warmth.

\section{F. Inverter}

An electrical converter is an device that changes electricity to various current. We should always keep in mind that electrical converter ne'er produces any power, the capacity is given by the DC supply. In most of the cases, the input DC voltages is sometimes lower .we have a tendency to can't use lower voltage within the household appliance. The input voltage, output voltage and frequency, over all power dealing with depend on the arranging of the precise device or electronic equipment. The ability electrical converter is entirely electronic or is also a mix of mechanical effects and electronic electronic equipment. Statics inverters don't use moving half within the conversion method.

\section{SOLAR WIND HYBRID ENERGY SYSTEMS}

The thing made by combining two or more different elements is refer as hybridization. We need hybridization for increasing output, fulfilling demand of consumer and providing uninterrupted power supply. This methodology is on ideal various in areas wherever wind rate $5.6 \mathrm{~m} / \mathrm{s}$ is out there. because the wind doesn't blow all the time nor will sun shine any time, star and alternative energy alone are poor power sources. Coupling of photo voltaic and alternative energy sources in conjunction with storage batteries to hide the periods of your time while not sun or wind provides a sensible type of power generation.

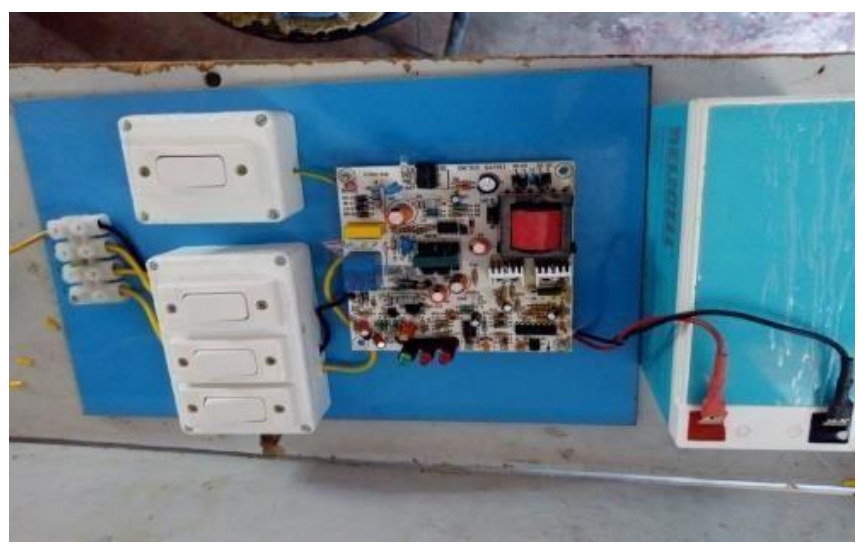

Fig. (ii) Battery with Inverter Ref [4]

The system creates a complete energy sources that's each dependable and consistent that is named the solar-wind hybrid system. For the most part, these sun powered radiation cross breed frameworks are able to do little capacities. The everyday power generation capacities of photo voltaic and wind hybrid system are within the vary from $1 \mathrm{kw}$ to $10 \mathrm{kw}$

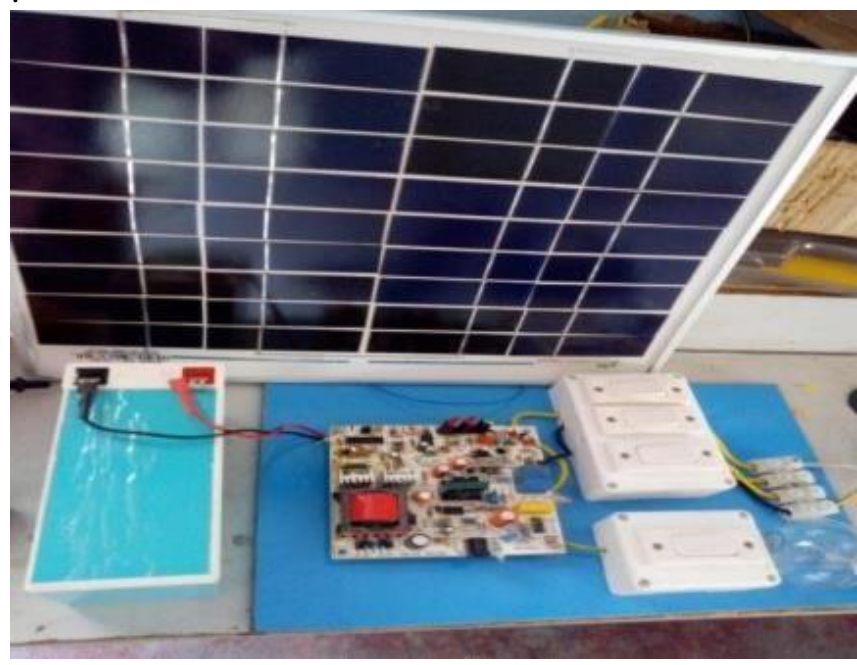

Fig. (iii) Photovoltaic Module and Battery with Inverter

\section{RESULT AND DISCUSSION}

In this paper we are using the 10Watts solar photo system and 30Watts Wind turbine system both are parallel connected to obtain the maximum power through charge controller. The output Power of the wind turbine is mainly depends upon the wind velocity and other factors in this work $30 \mathrm{~W}$ and $12 \mathrm{~V}$ small wind turbine used it is gives the higher power at the wind velocity is higher than $5 \mathrm{~m} / \mathrm{s}$. the below Table. II and Graph shows the Power generation per day. The PV framework will work more contrasted with the breeze turbine, which means the PV cluster serves the base burden. The power generation from the breeze turbine is limited because of the lower wind speed at the site. A portion of the energy demand for a personal house, farm house, a tiny low company, anacademic establishment or associate dwell ing betting on the necessity at the positioning. 
Table. II Power generation for hybrid system per Day

\begin{tabular}{|c|l|c|c|}
\hline S.No & Days & $\begin{array}{l}\text { PV Power in } \\
\text { Watts }\end{array}$ & $\begin{array}{l}\text { Wind } \\
\text { Power in } \\
\text { Watts }\end{array}$ \\
\hline 1 & Day 1 & 8 & 15 \\
\hline 2 & Day 2 & 9 & 16 \\
\hline 3 & Day 3 & 9.2 & 18 \\
\hline 4 & Day 4 & 9.5 & 21 \\
\hline 5 & Day 5 & 8 & 20 \\
\hline 6 & Day 6 & 8.6 & 15 \\
\hline
\end{tabular}

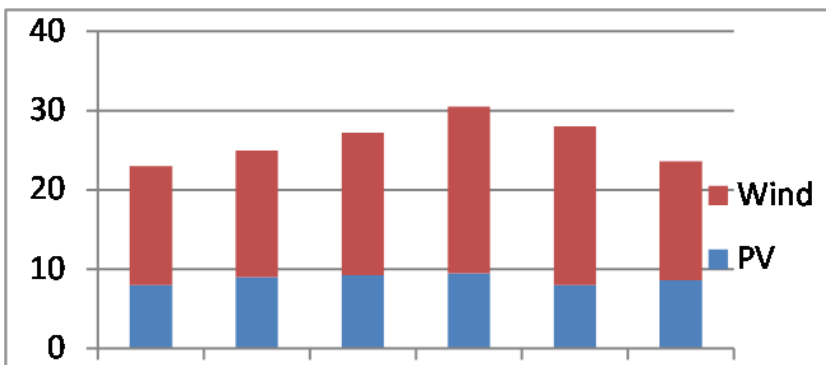

Day 1 Day 2 Day 3 Day 4 Day 5 Day 6

Fig (iv) Power generation per days

\section{CONCLUSION}

In this work was a small Solar Photo voltaic and Wind based Hybrid Energy System was implemented. wherever used has been provided with the power produced from the breeze and sunlight based vitality. It decreases the reliance on one single source and has expanded the unwavering quality. Thus we could improve the proficiency of the framework as contrasted and their individual method of generation.

\section{REFERENCES}

1. Arjun A. K, Athul S., Mohamed Ayub, Neethu Rames and Anith Krishnan," Micro-Hybrid Power Systems - A Feasibility Study", Journal of Clean Energy Technologies, Vol. 1, No. 1, January 2013,pp27-32 .

2. J.B.V.Subrahmanyam, P.K.Sahoo and Madhukarreddy," Local PV-Wind hybrid systems development for supplying electricity to industry"ActaElectrotechnica,Vol.53,No.1,2012,pp 10-15.

3. N.Sivaramakrishna \& Ch.Kasi Ramakrishna Reddy," Hybrid Power Generation through combined solar -Wind power and modified solar panel" International journal of engineering trends and technology (ijett) Volume4Issue5- May 2013,pp1414-1417.s

4. E.F.Ribeiro,A.J Marques Cardoso, and C. Boccaletti, "Uninterruptible Energy Production in StandaPower Systems for Telecommunications," International Conference on Renewable Energies and Power Quality (ICREPQ'09), Valencia (Spain), 15 th to 17 th April, 2009..

5. A.O.Ciuca,I.B.Istrate, and M Scripcariu,"Hybrid Power-Application for Tourism in Isolated Areas,"World Academy of Science, Engineering and Technology 53 2009, pp. 264-269.

6. K. Ch. Karasavvas, "Modular Simulation of a Hybrid Power System with Diesel, Photovoltaic Inverter and Wind Turbine Generation," Journal of Engineering Science and Technology Review 1(2008),pp. 38-40.181-81985,

7. B E. Muljadi and H. E Mckenna, "Power Quality Issues in a Hybrid Power System," IEEE-IAS 2001 Conference Chicago, IIIinois, September 30, 2001- October 4, 2001.

8. E. B. Hreinsson and L. A Barroso, "Defining Optimal Production Capacity in a Purely HydroelectricpowerStation,'IEEE 2nd International Conference on Electric Utility Deregulation, Restructuring and Power Technologies(DRPT 2004), April 5 th-8 th, 2004, HongKong.

9. B. Chitti Babu and K. B. Mohanty, "Doubly-fed Induction Generator for Variable Speed Wind Energy Conversion Systems-Modeling \&
Simulation," International Journal of Computer and Electrical sEngineering Vol.2,No.1,February,2010,1793- 8163,pp. 141-147.

10. S. A. abbasi and Naseema Abbasi, "Renewable Energy Sources and Their Environmental Impact," Prentice Hall of India Private Limited, 2005, pp.36.

11. V. K. Mehta, Rohit Mehta, "Principles of Power System,"S. Chand and Company Ltd, 2004,pp.17-19.. 29, no. 9, september 2014.

12. J S Poorani, R Murugan ,"A Non-Linear Controller for Forecasting the Rising Demand for Electric Vehicles Applicable to Indian Road Conditions", International Journal of Electrical and Computer Engineering Vol.6,issue 5, October 2016, pp. 2274 2281 .5publication.

\section{AUTHORS PROFILE}

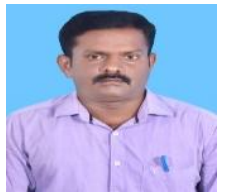

G. Esakkimuthu was born in Eravarpatti, Sivakasi, Tamil Nadu, India. He received his UG degree in Electrical Engineering from Anna University, Chennai in 2006 and M.E. degree in High Voltage Engineering from Anna University, Tirunelveli, Tamil Nadu, India, in 2009. He is pursuing $\mathrm{PhD}$ in Kalasalingam Academy of Research and Education, Krishnanakoil, Tamil Nadu, India.

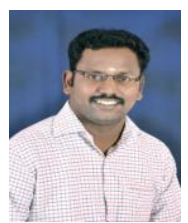

K. Rajesh was born in Rajapalayam, Tamil Nadu, India, in May 1987. He received his UG degree in Electrical Engineering from Anna University, Chennai in 2008 and M.E. degree in Power Systems Engineering from Anna University, Tirunelveli, Tamil Nadu, India, in 2011. Since July 2011, he has been working as an Assistant Professor in the Department of Electrical \& Electronics Engineering, Kalasalingam University, Krishnankoil, Virudhunagar District, Tamil Nadu and India.

He has attended several international conferences and he has been actively involving himself in research since 2013. Three of his research papers have been published in international journals and a research paper has been published in national journal. His current research interests include generation expansion planning, energy planning, power system optimization and power system control. He has actively participated in various faculty development programs, symposiums, orientation programs, workshops and national seminars. He has received Teaching Competency Award in the year 2015 and Research Competency Award in the year 2015 \& 2017. He is a Lifemember of ISTE and Member of IE(I).

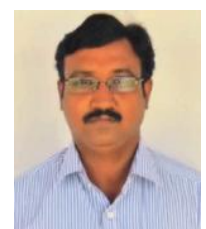

A. Ramkumar received the Ph.D degree from Kalasalingam Academy of Research andEducation in the year of 2014. He received the M.E (Power Systems) degree from Faculty of Engineering and Technology, Annamalai University, Chidambaram, Tamil Nadu, India, in2002 and received the B.E (Electrical and Electronics Engineering) from Thiagarajar Collegeof Engineering, M.K. University, Madurai, Tamil Nadu, India in the year of 1997. He hasbeen working as a Associate Professor in the Department of Electrical and ElectronicsEngineering, Kalasalingam Academy of Research and Education, Srivilliputhur, Tamil Nadu,since 2003. He is having more than 19 years' experience in the field of teaching. His researchinterests include Renewable Energy, Power System Planning, Power System Analysis, HighVoltage DC transmission Systems, Reactive Power Compensation, Flexible ACtransmissions Systems, Electrical Machines and Power System Automation. He is a Lifemember of ISTE and Member of IE(I).

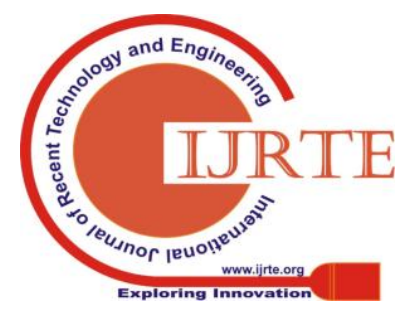

